\title{
Benefits and Toxicity of Disulfiram in Preclinical Models of Nephropathic Cystinosis
}

\author{
Anna Taranta ${ }^{1, *}$, Mohamed A. Elmonem ${ }^{2,3}{ }^{1}$, Francesco Bellomo ${ }^{1}{ }^{0}$, Ester De Leo ${ }^{1}$, Sara Boenzi ${ }^{4}$, \\ Manoe J. Janssen ${ }^{5}$, Amer Jamalpoor ${ }^{5}$, Sara Cairoli ${ }^{4}$, Anna Pastore ${ }^{6}$ (D), Cristiano De Stefanis ${ }^{7}$, Manuela Colucci ${ }^{1}$, \\ Laura R. Rega ${ }^{1}$, Isabella Giovannoni ${ }^{8}$ (D), Paola Francalanci ${ }^{8}$ (D), Lambertus P. van den Heuvel ${ }^{3,9}$, \\ Carlo Dionisi-Vici ${ }^{4}$, Bianca M. Goffredo ${ }^{4}$, Rosalinde Masereeuw ${ }^{5}$ (D), Elena Levtchenko ${ }^{3,10}(\mathbb{D}$ \\ and Francesco Emma 1,11
}

check for updates

Citation: Taranta, A.; Elmonem, M.A.; Bellomo, F.; De Leo, E.; Boenzi, S.; Janssen, M.J.; Jamalpoor, A.;

Cairoli, S.; Pastore, A.; De Stefanis, C.; et al. Benefits and Toxicity of Disulfiram in Preclinical Models of Nephropathic Cystinosis. Cells 2021, 10, 3294. https://doi.org/10.3390/ cells10123294

Academic Editor: Akito Maeshima

Received: 14 October 2021

Accepted: 18 November 2021

Published: 24 November 2021

Publisher's Note: MDPI stays neutral with regard to jurisdictional claims in published maps and institutional affiliations.
1 Renal Diseases Research Unit, Genetics and Rare Diseases Research Division, Bambino Gesù Children's Hospital, IRCCS, 00165 Rome, Italy; francesco.bellomo@opbg.net (F.B.); ester.deleo@opbg.net (E.D.L.); manuela.colucci@opbg.net (M.C.); laurarita.rega@opbg.net (L.R.R.); francesco.emma@opbg.net (F.E.)

2 Department of Clinical and Chemical Pathology, Faculty of Medicine, Cairo University, Cairo 11956, Egypt; mohamed.abdelmonem@kasralainy.edu.eg

3 Laboratory of Pediatric Nephrology, Department of Development and Regeneration, KU Leuven, 3000 Leuven, Belgium; Bert.vandenHeuvel@radboudumc.nl (L.P.v.d.H.); elena.levtchenko@uzleuven.be (E.L.)

4 Laboratory of Metabolic Biochemistry Unit, Department of Pediatric Medicine, Bambino Gesù Children's Hospital, IRCCS, 00165 Rome, Italy; sara.boenzi@opbg.net (S.B.); sara.cairoli@opbg.net (S.C.); carlo.dionisivici@opbg.net (C.D.-V.); bianca.goffredo@opbg.net (B.M.G.)

5 Division of Pharmacology, Utrecht Institute for Pharmaceutical Sciences, Utrecht University, 3584 CG Utrecht, The Netherlands; m.j.janssen1@uu.nl (M.J.J.); a.jamalpoor@uu.nl (A.J.); r.masereeuw@uu.nl (R.M.)

6 Genetics and Rare Diseases Research Division, Bambino Gesù Children's Hospital, IRCCS, 00165 Rome, Italy; anna.pastore@opbg.net

7 Histology-Core Facility, Bambino Gesù Children's Hospital, IRCCS, 00165 Rome, Italy; cristiano.destefanis@opbg.net

8 Department of Pathology, Bambino Gesù Children's Hospital, IRCCS, 00165 Rome, Italy; isabella.giovannoni@opbg.net (I.G.); paola.francalanci@opbg.net (P.F.)

9 Department of Pediatric Nephrology, Radboud University Medical Center, 6525 GA Nijmegen, The Netherlands

10 Division of Pediatric Nephrology, Department of Pediatrics, University Hospitals Leuven, 3000 Leuven, Belgium

11 Division of Nephrology, Department of Pediatric Subspecialities, Bambino Gesù Children's Hospital, IRCSS, 00165 Rome, Italy

* Correspondence: anna.taranta@opbg.net; Tel.: +39-06-6859-2997

Abstract: Nephropathic cystinosis is a rare disease caused by mutations of the CTNS gene that encodes for cystinosin, a lysosomal cystine/H+ symporter. The disease is characterized by early-onset chronic kidney failure and progressive development of extra-renal complications related to cystine accumulation in all tissues. At the cellular level, several alterations have been demonstrated, including enhanced apoptosis, altered autophagy, defective intracellular trafficking, and cell oxidation, among others. Current therapy with cysteamine only partially reverts some of these changes, highlighting the need to develop additional treatments. Among compounds that were identified in a previous drug-repositioning study, disulfiram (DSF) was selected for in vivo studies. The cystine depleting and anti-apoptotic properties of DSF were confirmed by secondary in vitro assays and after treating $\mathrm{Ctns}^{-/}$mice with $200 \mathrm{mg} / \mathrm{kg} /$ day of DSF for 3 months. However, at this dosage, growth impairment was observed. Long-term treatment with a lower dose $(100 \mathrm{mg} / \mathrm{kg} /$ day $)$ did not inhibit growth, but failed to reduce cystine accumulation, caused premature death, and did not prevent the development of renal lesions. In addition, DSF also caused adverse effects in cystinotic zebrafish larvae. DSF toxicity was significantly more pronounced in $\mathrm{Ctns}^{-/}$mice and zebrafish compared to wild-type animals, suggesting higher cell toxicity of DSF in cystinotic cells.

Keywords: cystinosis; disulfiram; mice; zebrafish 


\section{Introduction}

Nephropathic cystinosis (NC) is an inherited metabolic disease secondary to mutations in the CTNS gene, which encodes for cystinosin, a cystine proton symporter allowing efflux of cystine from lysosomes [? ]. In patients with NC, cystine progressively accumulates in nearly all tissues. Symptoms begin with renal Fanconi syndrome in the first year of life, followed by cystine crystal depositions in the cornea [? ]. In time, patients develop other symptoms, including hypothyroidism, pancreatic insufficiency, gonadal failure, poor growth, myopathy, cholestatic liver disease, and central and peripheral nervous system involvement [? ]. Kidney damage is characterized in part by increased apoptosis of proximal tubular cells in mice [? ], confirming previous in vitro studies showing that cystinotic cells are more sensitive to apoptotic stimuli [? ? ].

Cysteamine was approved for the treatment of NC in the 1990s, and allows cystine clearance from lysosomes through the formation of a mixed cysteine-cysteamine disulfide that can exit lysosomes through the PQLC2 transporter [? ]. Cysteamine significantly improves NC, but does not cure the disease. Despite adequate treatment, the majority of patients progress to end-stage kidney disease in the second or third decade of life [? ].

In order to identify new molecules that can improve the treatment of patients with NC, two drug screenings were performed using conditionally immortalized human cystinotic proximal tubule cells [? ]. A high throughput screening based on cell cystine concentration identified 24 compounds that reduced cystine content by $>50 \%$. Similarly, a high content screening identified 27 compounds that decreased apoptosis (caspase- $3 / 7$ positivity) by $>40 \%$ [? ]. We combined results from these two screenings, and identified disulfiram (DSF) as a potential treatment for cystinosis. Herein, we report the results of in vitro and in vivo studies assessing the efficacy of DSF in cystinotic human proximal tubule epithelial cells, mice, and zebrafish. Our results confirm the cystine-depleting and anti-apoptotic effects of DSF, but show significant toxicity that is enhanced in cystinotic animal models.

\section{Materials and Methods}

\subsection{Cell Culture}

In vitro assays were performed using conditionally immortalized proximal tubule epithelial cells (ciPTECs) obtained from the urine of a patient with nephropathic cystinosis or from healthy controls that have been described elsewhere [? ] and were provided to us by Radboud University Medical Center (Nijmegen, The Netherlands). Growth media included DMEM-F12 medium supplemented with $10 \%$ FBS, Penicillin $(100 \mathrm{U} / \mathrm{mL}) /$ Streptomycin $(0.1 \mathrm{mg} / \mathrm{mL})$, ITS $(5 \mu \mathrm{g} / \mathrm{mL}$ Insulin, $5 \mu \mathrm{g} / \mathrm{mL}$ Transferrin, $5 \mathrm{ng} / \mathrm{mL}$ Selenium), hydrocortisone $(36 \mathrm{ng} / \mathrm{mL})$, EGF $(10 \mathrm{ng} / \mathrm{mL})$, and tri-iodothyronine $(40 \mathrm{pg} / \mathrm{mL})$. Cells were grown at $33^{\circ} \mathrm{C}$ for proliferation and $37^{\circ} \mathrm{C}$ for 7 days to allow differentiation. Medium, FBS and Penicillin/Streptomycin were supplied by Gibco (Thermo Fisher Scientific, Waltham, MA, USA). All other reagents were from Sigma-Aldrich (Merck, Darmstadt, Germany).

\subsection{Quantitative Determination of Cystine in Cells}

Cystinotic ciPTECs were seeded at a density of $5 \times 10^{4}$ cells/well in 48-well plates. After $48 \mathrm{~h}$, cells grown at $33^{\circ} \mathrm{C}$ were treated with different concentrations of DSF (from 0.1 to $100 \mu \mathrm{M}$ ) and cysteamine. After $24 \mathrm{~h}$, cells were washed twice in PBS and lysed in $75 \mu \mathrm{L}$ of $10 \mathrm{mM}$ N-ethylmaleimide (NEM) with five freezing/thawing cycles. Cell lysates were precipitated with $75 \mu \mathrm{L}$ of $10 \% 5$-sulfosalicylic acid (SSA) and left overnight at $4{ }^{\circ} \mathrm{C}$. Plates were then centrifuged at $3900 \times g$ for 15 min at $4{ }^{\circ} \mathrm{C}$. Supernatant $(25 \mu \mathrm{L})$ was analyzed by reverse-phase high-performance liquid chromatography and fluorescence detection (HPLC-FLD) for thiol measurements [? ]. The remaining samples were used to measure protein content after adding $50 \mu \mathrm{L}$ of $0.1 \mathrm{M} \mathrm{NaOH}$ and BCA reagent (Bio Rad Laboratories, Hercules, CA, USA). 


\subsection{Measurement of Apoptosis in Cells}

Cystinotic ciPTECs were seeded at a density of $4 \times 10^{3}$ cells/well in 384-well plates coated with poly-D-lysine (Perkin Elmer, Waltham, MA, USA). After 48 h, cells were pre-treated with different concentrations of DSF for one hour and apoptosis was induced with Fas-ligand $(0.5 \mu \mathrm{g} / \mathrm{mL})$ and cycloheximide $(10 \mu \mathrm{g} / \mathrm{ml})$ for $5 \mathrm{~h}$. ciPTECs were then incubated with $4 \mu \mathrm{M}$ of cellEvent probe (Invitrogen life technologies, Carlsbad, CA, USA) for $30 \mathrm{~min}$. This reagent is a cell permeant dye that emits fluorescence when cleaved by caspases-3/7. For the analysis, cells were fixed in $4 \%$ paraformaldehyde and nuclei were stained with Hoechst 33258. Cells were imaged with the automated Opera system (Perkin Elmer, Beaconsfield, UK). Apoptotic cells were quantified as positive nuclei/total number of cells. We performed 16 replicas per each treatment; 250 cells/well were analyzed.

\subsection{Cell Viability Assay}

Cystinotic and wild-type ciPTECs were seeded at a density of $55 \times 10^{3}$ cells $/ \mathrm{cm}^{2}$ and grown at $33^{\circ} \mathrm{C}$ for $24 \mathrm{~h}$ and $37^{\circ} \mathrm{C}$ for 7 days. Cells were then treated for $24 \mathrm{~h}$ with L-cysteine $(1.8 \mathrm{mM})$, N-acetyl cysteine $(1.8 \mathrm{mM})$, DSF (different concentrations; see below), or a combination of the above. Cell viability was evaluated using the PrestoBlue Cell Viability Reagent (Thermo Fisher Scientific) according to the manufacturer's instructions.

\subsection{Redox Status}

Cystinotic ciPTECs were seeded and grown as described above. After treatment with $10 \mu \mathrm{M}$ DSF, cells were incubated with CellROX Green Reagent (Thermo Fisher Scientific) for $30 \mathrm{~min}$ at room temperature and reactive oxygen species (ROS) were measured by live cell flow cytometry. GSH and GSSG levels were analyzed as described by Jamalpoor et al., who have performed extensive metabolomic investigations in the same cell conditions [? ].

\subsection{Tandem Mass Spectrometry}

L-cystine ( $416 \mu \mathrm{M}$ at pH 7.4) and DSF (200 $\mu \mathrm{M}$ in DMSO) were stirred overnight at RT. Tandem mass spectrometry analyses were carried out on a 4000-QTRAP mass spectrometer (ABSciex, Toronto, ON, Canada), equipped with a Turbo Ion Spray Source operating in positive ion mode with a needle potential of $5500 \mathrm{~V}$. The flow rate of mobile phase was set at $150 \mu \mathrm{L} / \mathrm{min}$ and infused into the spectrometer using an Agilent 1290 infinity pump (Agilent Technologies Inc., Wilmington, DE, USA). Instrument setting and calibration were performed with $10 \mu \mathrm{M}$ DSF and $10 \mu \mathrm{M}$ cystine solutions. The analysis was conducted to evaluate the formation of hybrid disulfide molecule of $269 \mathrm{~m} / \mathrm{z}$.

\subsection{Studies on Cystinotic Mice}

Ctns knockout mice (C57BL/6 background) were kindly provided by Dr. Corinne Antignac [? ]. Animal care and experimental procedures were conducted in accordance with the European 2010/63/EU directive on the protection of animals used for scientific purposes, and authorized by the Italian Ministry of Health (authorization number 230/2015-PR).

Drugs were mixed with standard 4RF21 diet and prepared in pellets (Mucedola, Settimo Milanese, Italy). Concentrations of drug in pellets were calculated based on the average daily food intake (approximately $3 \mathrm{~g} /$ day) and body weight (approximately $22 \mathrm{~g}$ ) of female mice, to administer estimated doses of 50, 100, and $200 \mathrm{mg} / \mathrm{kg}$ of body weight/day of DSF. Female mice started treatment at 2 months of age. Animal length and weight were measured monthly. Every two months, mice were acclimatized in metabolic cages for $24 \mathrm{~h}$, and their urine was collected for $24 \mathrm{~h}$. Blood samples were collected at sacrifice. Analyzed parameters included urine volume, electrolytes, glucose, proteins, BUN, and creatinine. Measurements were performed by the Appia Laboratory (Rome, Italy). In addition, low-molecular weight proteinuria was estimated using the Clara cell 16 protein (CC16) as a marker (Biomatik Corporation, Kitchener, ON, Canada). Power analysis was performed to calculate the minimum number of mice per treatment arm. 


\subsection{Quantitative Determination of Diethyldithiocarbamate (DDC) and Cystine in Tissues}

For DDC quantitative determination, $10 \mathrm{mg}$ of tissue samples were sonicated in $100 \mu \mathrm{L}$ $\mathrm{NaCl} 0.9 \%$ solution. The supernatant $(50 \mu \mathrm{L})$ was extracted with $200 \mu \mathrm{L}$ of acetonitrile, vortexed and centrifuged at $18,000 \times g$ for $9 \mathrm{~min}$. A solution of DDC was prepared by dissolving in methanol to make up a standard solution of $1 \mathrm{mg} / \mathrm{mL}$.

For cystine quantitative determination, tissue samples were sonicated in the presence of $10 \mathrm{mM}$ NEM. Homogenates were centrifuged at $1000 \times g$ for $5 \mathrm{~min}$ and supernatants were mixed with $10 \%$ SSA ( $3: 1$ volume ratio), incubated at $4{ }^{\circ} \mathrm{C}$ for $60 \mathrm{~min}$, and centrifuged at $20,000 \times g$ for $15 \mathrm{~min}$. The supernatants $(50 \mu \mathrm{L})$ were spiked with $50 \mu \mathrm{L}$ of the internal standard solution (Cystine d6). The mixture was then extracted with $200 \mu \mathrm{L}$ of acetonitrile, vortexed and centrifuged at $18,000 \times g$ for $9 \mathrm{~min}$. Protein concentrations were measured on the first supernatant using Bio-Rad Protein Assay Reagent Kit (Bio-Rad Laboratories Inc.), following the manufacturer's protocol. All chemicals were of analytical grade and were obtained from Sigma-Aldrich (St. Louis, MO, USA).

Liquid chromatography/mass spectrometry analysis was performed using a UHPLC Agilent 1290 Infinity II 6470 (Agilent Technologies Inc.) equipped with an ESI-JET-STREAM source operating in positive ion (ESI+) mode. The MassHunter Workstation software (Agilent Technologies Inc.) was used for data analysis. InfinityLab Poroshell 120 HILIC $1.9 \mu \mathrm{m} 100 \times 2.1 \mathrm{~mm}$ (Agilent Technologies Inc.) were used as separation columns. A full validation assay was performed, including selectivity, specificity, linearity, limits of quantification, accuracy, precision, matrix effects, recovery, and stability.

\subsection{Measurement of Apoptosis in Tissue}

Immunohistochemistry was performed on $2 \mu \mathrm{m}$ thick sections obtained from formalinfixed tissue embedded in paraffin. After dewaxing and rehydrating, heat-induced epitope retrieval was performed by boiling the slides with sodium citrate (pH 6) (Dako, Glostrup, Denmark). Endogenous peroxidase was blocked with $3 \%$ hydrogen peroxide and then with $5 \%$ BSA. Sections were incubated overnight at $4{ }^{\circ} \mathrm{C}$ with rabbit monoclonal (9661S) to Cleaved Caspase-3 (Cell Signaling Technology, Danvers, MA, USA), diluted 1:400. Detection of the primary antibody was performed by using the appropriate secondary biotinylated antibody (K8024) (ready to use) (Dako, Carpinteria, CA, USA) and the peroxidase DAB kit (Dako, Carpinteria, CA, USA). Counterstaining was performed with hematoxylin solution Gill2.

\subsection{Zebrafish Assays}

Experiments were performed on wild-type and cystinotic zebrafish larvae that have already been characterized [? ]. Adult fish were raised at $28.5^{\circ} \mathrm{C}$, on a $14 / 10 \mathrm{~h} \mathrm{light/dark}$ cycle under standard aquaculture conditions [? ]. Fertilized wild-type or cystinotic embryos (20-30 per well) were transferred to 6-well plates containing $5 \mathrm{~mL}$ of clean egg water (Instant Ocean Sea Salts $60 \mu \mathrm{g} / \mathrm{mL}+$ methylene blue $0.5 \mathrm{ppm}$ ). DSF was dissolved directly in the egg water at the specified concentrations. Embryos were incubated at $28.5^{\circ} \mathrm{C}$ in the dark and the medium was refreshed daily. Wells were cleaned from debris daily and dead embryos were removed and counted. Larvae viability was monitored for the first $96 \mathrm{~h}$ postfertilization (hpf). Hatching rates were calculated in surviving embryos at 48, 72, and $96 \mathrm{hpf}$. Final deformity rates were evaluated at $96 \mathrm{hpf}$. Animal care and experimental procedures were conducted in accordance with the ethical committee guidelines for laboratory animal experimentation at KU Leuven, in accordance with the European 2010/63/EU directive on the protection of animals used for scientific purposes.

For cystine quantitative determination, homogenates of surviving zebrafish larvae were assessed using liquid chromatography tandem mass spectrometry. Groups of 30-60 larvae for each condition were homogenized by sonication in $200 \mu \mathrm{L}$ of $5 \mathrm{mM}$ NEM in $0.1 \mathrm{M}$ PBS. Then, $100 \mu \mathrm{L}$ of $12 \%$ SSA was added to each homogenate and samples were centrifuged for $10 \mathrm{~min}$ at $4{ }^{\circ} \mathrm{C}$ at $12,000 \times \mathrm{g}$. Supernatants were used for cystine measurements and stored at 
$-80{ }^{\circ} \mathrm{C}$. Pellets for protein measurements were dissolved overnight at $4{ }^{\circ} \mathrm{C}$ in $300 \mu \mathrm{L}$ of $0.1 \mathrm{M}$ $\mathrm{NaOH}$, and stored at $-80^{\circ} \mathrm{C}$.

\subsection{Statistical Analysis}

Categorical data are represented as counts and percentages. Continuous normal data are expressed as mean \pm standard error of the mean. Continuous data that do not follow a normal distribution are expressed as median value and interquartile range. Normality of data was tested with the D'Agostino-Pearson test. The Chi-squared test was used to compare hatching and deformity rates. Student's $t$-test, ANOVA followed by Bonferroni's post-hoc correction, and the Mann-Whitney U-test were used as appropriate. Survival was estimated by the Kaplan-Meier method and assessed by the Log-Rank test. All $p$-values are two-sided and considered significant for $p<0.05$. Statistical analyses were performed using the GraphPad Prism 6 software (San Diego, CA, USA).

\section{Results}

\subsection{In Vitro DSF Studies}

At the end of two drug screenings [? ] that used cystine accumulation and apoptosis as read-outs, we identified six compounds that showed positive effects in both assays. Among these, we selected DSF for future tests, based on its pharmacological properties and known safety profile.

Unlike cysteamine, which is the current standard of care for cystinosis, DSF is a disulfide compound composed of two S-methyl-N,N-diethyldithiocarbamate (DDC), lacking free sulfhydryl residues (Figure 1A,B).

We hypothesized that under physiologic conditions, cystine and DSF are in equilibrium with their reduced form, allowing the formation of mixed disulfides. To this end, we co-incubated liquid solutions of DSF and cystine for $14 \mathrm{~h}$ at room temperature and analyzed them by tandem mass spectrometry. As illustrated in Figure 1C, several mixed disulfides formed, indicating that the cystine-lowering effect of DSF is likely mediated by the formation of mixed disulfides that can bypass the non-functioning cystinosin transporter, similarly to what has been described for cysteamine.

We then performed dose-response experiments to identify the lowest concentration of DSF that prevented cystine accumulation and apoptosis in cystinotic ciPTEC and compared the effect with cysteamine. As shown in Figure 2A, DSF lowered cystine slightly better (IC50: $9 \mu \mathrm{M}$ ) than cysteamine (IC50: $22 \mu \mathrm{M}$ ). DSF also prevented apoptosis at concentrations $\geq 2.5 \mu \mathrm{M}$ (Figure 2B). 
A<smiles>CCN(CC)C(=S)CSC(=S)N(CC)CC</smiles>

a: DISULFIRAM: [M] ${ }^{+} 297.3 \mathrm{~m} / \mathrm{z}$
B

DDC<smiles>CCN(CC)C(=S)S</smiles><smiles>NC(C(=O)O)C1CC2CC1SC2C(N)C(=O)O</smiles><smiles>NC(CS)C(=O)O</smiles>

b: CYSTINE: [M] ${ }^{+} 241.3 \mathrm{~m} / \mathrm{z}$
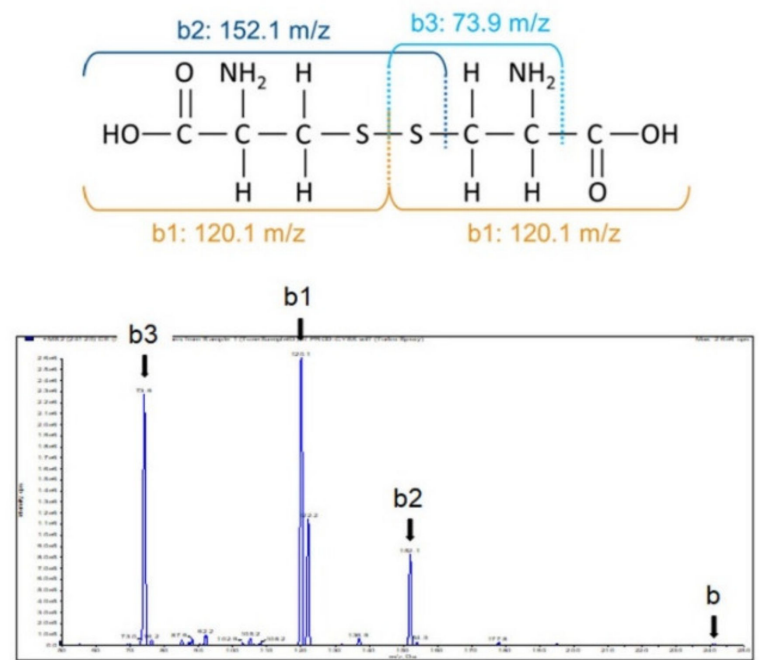

C

c: DDC-CYSTEINE: [M] $269 \mathrm{~m} / \mathrm{z}$

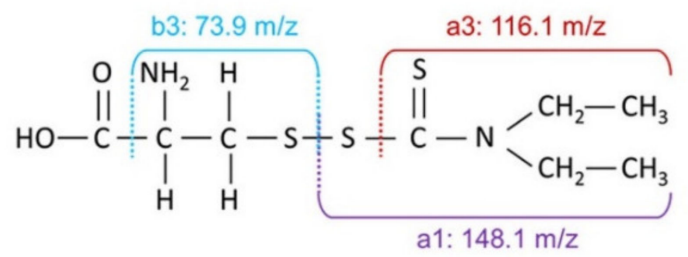

b3
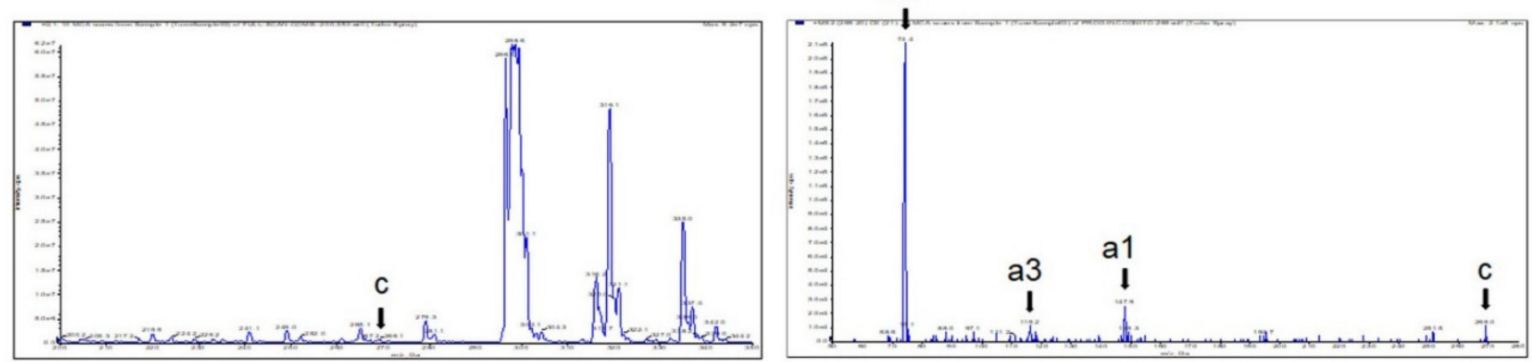

Figure 1. MS/MS determination of DSF, cystine and mixed-disulfides. (A) Chemical structures of DSF and diethyldithiocarbamate (DDC). The chromatogram shows peaks corresponding to DSF (a), half molecule of DSF (a1) and two molecules obtained by breaking the carbon-sulfur bond (a2 and a3). (B) Chemical structures of cystine and cysteine. The chromatogram shows peaks corresponding to cystine (b), half molecule of cystine (b1), and fragments obtained after breaking carbon-sulfur (b2) and carbon-carbon bonds (b3). (C) Mixed disulfides. The chromatogram on the left panel shows a peak indicating the formation of a mixed-disulfide with a calculated mass-charge ratio $(\mathrm{m} / \mathrm{z})$ of 269 (c). The right panel shows the product ion scan for the $269 \mathrm{~m} / \mathrm{z}$ peak, identifying three fragments: the $148 \mathrm{~m} / \mathrm{z}$ peak corresponds to half molecules of DSF (a1), the $116 \mathrm{~m} / \mathrm{z}$ peak is produced by thiol-ester bond cleavage of DSF (a3), and the $74 \mathrm{~m} / \mathrm{z}$ peak corresponds to cystine (b3). 
A

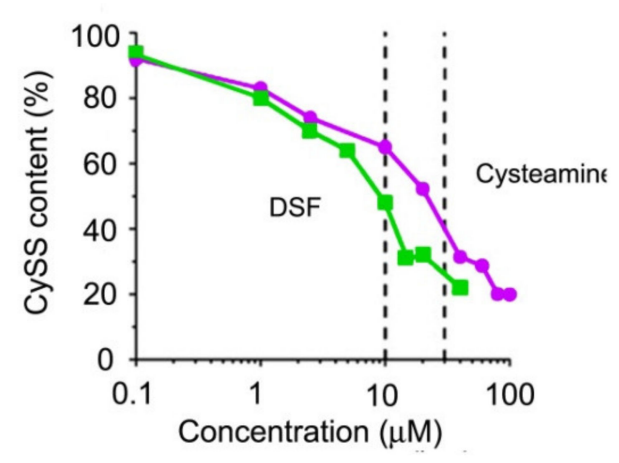

B

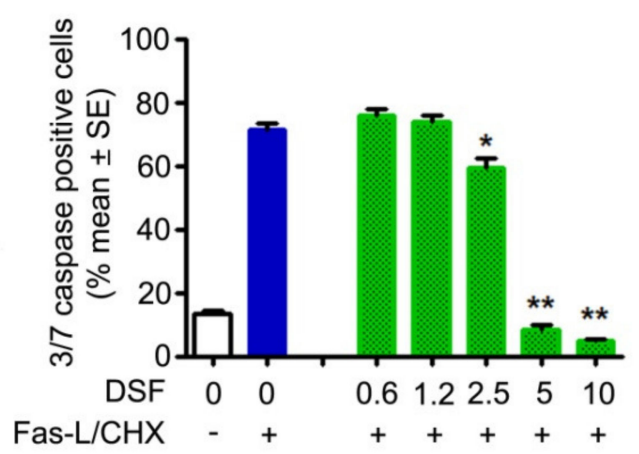

Figure 2. Cystine-depleting and anti-apoptotic proprieties of DSF. (A) Comparison of dose-response curves. Cystine (CySS) accumulation was measured after treatment for $24 \mathrm{~h}$ with the indicated concentrations of DSF and cysteamine in cystinotic ciPTECs. Vertical dashed lines indicate IC50 for DSF $(9 \mu \mathrm{M})$ and cysteamine $(22 \mu \mathrm{M})$. Data represent 4 independent experiments. (B) Anti-apoptotic dose response of DSF. The white and blue columns indicate spontaneous or induced apoptosis with Fas-Ligand (Fas-L) and cycloheximide (CHX) in cystinotic ciPTECs, respectively. The green columns indicate the treatment with DSF $(0.6-10 \mu \mathrm{M})$ in cells exposed to apoptotic stimuli. Data represent 3 independent experiments. ${ }^{*} p<0.005$ and ${ }^{* *} p<0.0005$ vs. blue column.

\subsection{In Vivo Studies: Murine Treatment with High DSF Dose}

Based on the above results, we treated Ctns knockout (KO) mice with DSF. KO and wild-type (WT) animals received DSF in food from the age of 2 months. Two different concentrations of DSF were initially used, corresponding to an estimated daily dose of 100 (low dose) or 200 (high dose) $\mathrm{mg} / \mathrm{kg}$ (see methods). We rapidly observed in both WT and KO animals significant growth impairment after DSF treatment, especially at the highest dose (Figures ??A and ??A). We therefore decided to sacrifice animals treated with the $200 \mathrm{mg} / \mathrm{kg} /$ day dose for three months (i.e., at 5 months of age). Biochemical and histopathological parameters were evaluated to measure kidneys and liver function.

From the kidney standpoint, untreated $\mathrm{KO}$ mice at 5 months of age had more glycosuria compared to WT animals, and developed marked low-molecular weight proteinuria (LMWP) (Table 1). Treatment with high-dose DSF decreased glucose excretion, increased calciuria, and had no impact on low-molecular weight proteinuria (Table 1). Serum creatinine and blood urea nitrogen levels were unchanged (data not shown).

Table 1. Urinary parameters in WT and KO mice treated with high DSF dose for three months.

\begin{tabular}{|c|c|c|c|c|c|}
\hline \multirow[b]{2}{*}{ Urine Tests } & \multirow[b]{2}{*}{$\begin{array}{l}\text { Measure } \\
\text { Unit }\end{array}$} & \multicolumn{2}{|c|}{ WT } & \multicolumn{2}{|c|}{ KO } \\
\hline & & Untreated & $\begin{array}{l}\text { DSF } \\
200\end{array}$ & Untreated & $\begin{array}{l}\text { DSF } \\
200\end{array}$ \\
\hline Albumin & $\begin{array}{l}\mu \mathrm{g} / \mathrm{mg} \\
\text { Creatinine }\end{array}$ & $\begin{array}{c}5.05 \\
{[3.49-12.1]}\end{array}$ & $\begin{array}{c}7.66 \\
{[6.59-11.1]}\end{array}$ & $\begin{array}{c}8.58 \\
{[5.02-9.79]}\end{array}$ & $\begin{array}{c}20.7 \\
{[10.5-76.3]}\end{array}$ \\
\hline Glucose & $\begin{array}{l}\mathrm{mg} / \mathrm{mg} \\
\text { Creatinine }\end{array}$ & $\begin{array}{c}0.29 \\
{[0.26-1.02]}\end{array}$ & $\begin{array}{c}0.34 \\
{[0.24-0.78]}\end{array}$ & $\begin{array}{c}7.59 \\
{[4.41-16.2]^{\S}}\end{array}$ & $\begin{array}{c}0.40 \\
{[0.28-1.66]}\end{array}$ \\
\hline LMWP & $\begin{array}{c}\mu \mathrm{g} / \mathrm{mg} \\
\text { Creatinine }\end{array}$ & $\begin{array}{c}38.2 \\
{[13.8-39.5]}\end{array}$ & $\begin{array}{c}37.7 \\
{[10.2-69.1]}\end{array}$ & $\begin{array}{c}157 \\
{[75.1-447]^{\S}}\end{array}$ & $\begin{array}{c}258 \\
{[79.6-474]}\end{array}$ \\
\hline Calcium & $\begin{array}{l}\mathrm{mg} / \mathrm{mg} \\
\text { Creatinine }\end{array}$ & $\begin{array}{c}0.12 \\
{[0.09-0.17]}\end{array}$ & $\begin{array}{c}0.12 \\
{[0.09-0.18]}\end{array}$ & $\begin{array}{c}0.21 \\
{[0.15-0.26]}\end{array}$ & $\begin{array}{c}1.17 \\
{[0.52-3.36]}\end{array}$ \\
\hline Phosphate & $\begin{array}{l}\mathrm{mg} / \mathrm{mg} \\
\text { Creatinine }\end{array}$ & $\begin{array}{c}0.60 \\
{[0.14-1.66]}\end{array}$ & $\begin{array}{c}1.51 \\
{[0.15-2.88]}\end{array}$ & $\begin{array}{c}0.66 \\
{[0.15-1.85]}\end{array}$ & $\begin{array}{c}2.58 \\
{[0.99-6.43]}\end{array}$ \\
\hline
\end{tabular}

Data are represented as median [interquartile range] $n=4$ mice per group. Low molecular weight proteins (LMWP), $200 \mathrm{mg} / \mathrm{kg} /$ day DSF dose (DSF 200). ${ }^{\S} p<0.05$ untreated WT mice vs. untreated KO mice; * $p<0.05$ untreated $\mathrm{KO}$ mice vs. treated $\mathrm{KO}$ mice. 
A

DSF

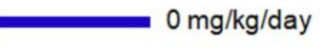

WT

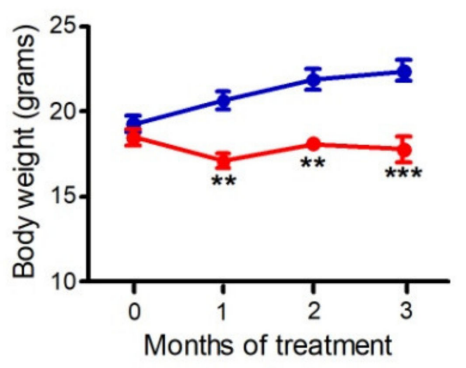

KO

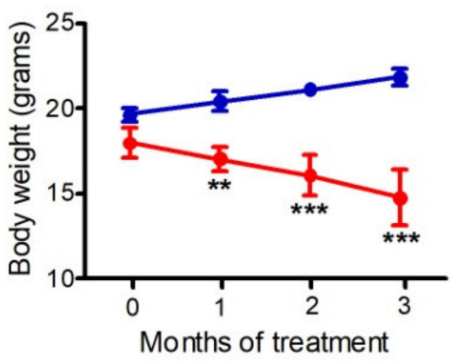

B

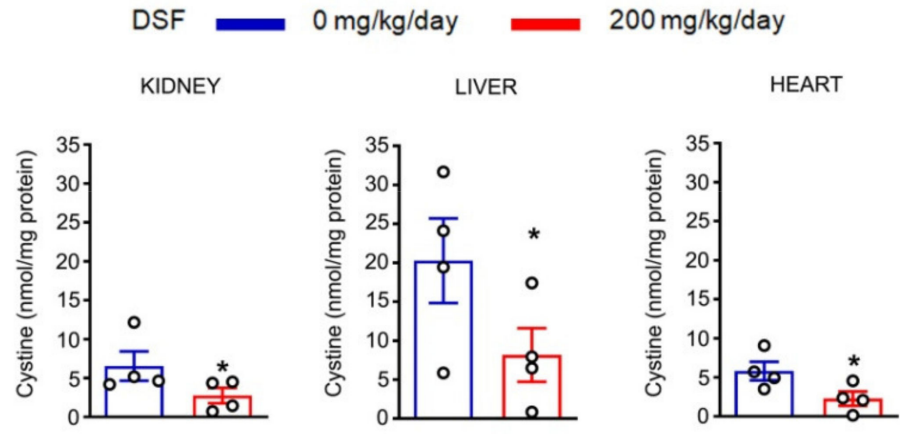

C

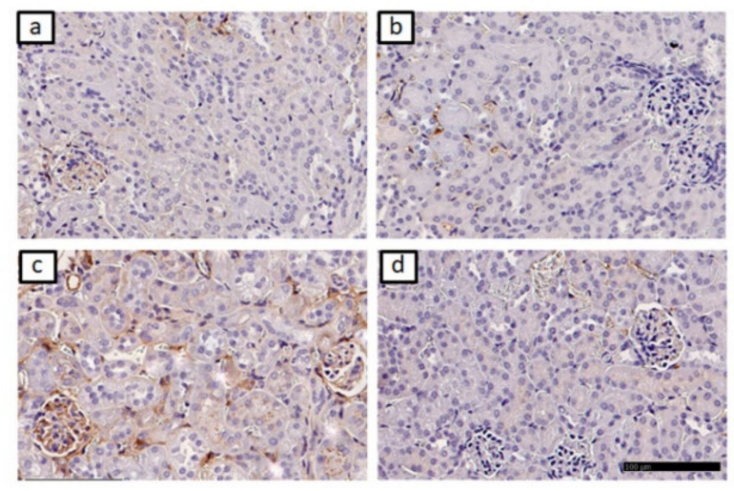

DSF $\bullet 0 \mathrm{mg} / \mathrm{kg} /$ day $\bullet 200 \mathrm{mg} / \mathrm{kg} /$ day

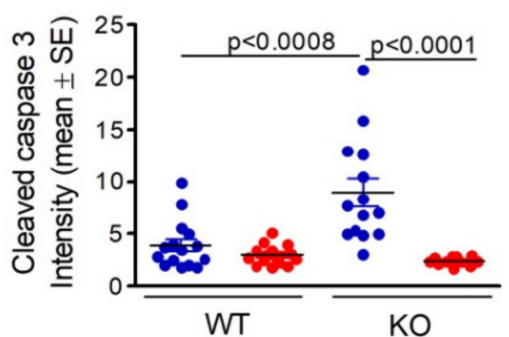

Figure 3. Short-term treatment with high DSF dose. Two-month-old mice were fed on standard or DSF-supplemented diet at an estimated dose of $200 \mathrm{mg} / \mathrm{kg}$ of body weight/day. (A) Body weight in animals fed on standard or DSF-supplemented diets for three months. Data are shown as mean $\pm \mathrm{SEM} ; n=9 \mathrm{WT}$ and $4 \mathrm{KO}$ mice; ${ }^{* *} p<0.005,{ }^{* * *} p<0.0005$ compared to untreated animals. (B) Cystine content in kidneys, liver, and heart of $\mathrm{KO}$ animals sacrificed at 5 months of age ( $n=4$ mice per group). Values are indicated as mean $\pm \mathrm{SEM} ;{ }^{*} p<0.05$ compared to untreated mice. (C) Representative immunohistochemistry images stained with anti-cleaved caspase- 3 antibodies in kidneys obtained from WT $(\mathbf{a}, \mathbf{b})$ and $\mathrm{KO}(\mathbf{c}, \mathbf{d})$ mice that were fed on standard $(\mathbf{a}, \mathbf{c})$ or DSFsupplemented $(\mathbf{b}, \mathbf{d})$ diets. Scale bar: $100 \mu \mathrm{m}$. The graph shows the mean cleaved caspase-3 intensity measured on five separate slides per animal ( $n=3$ mice per group). 
A

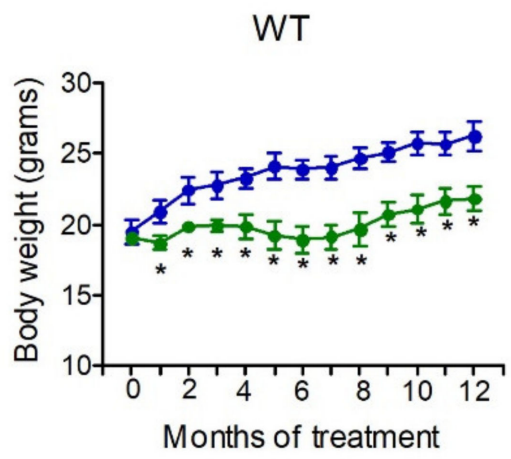

B

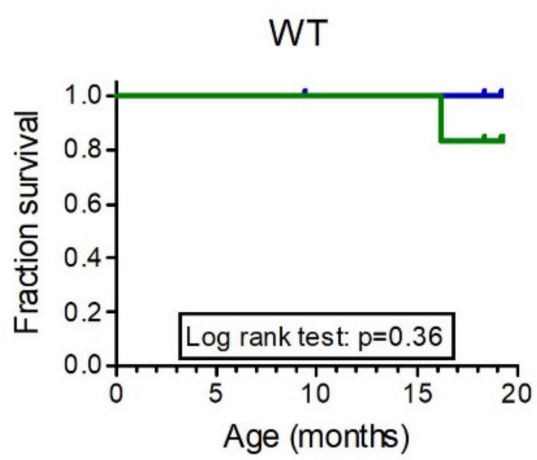

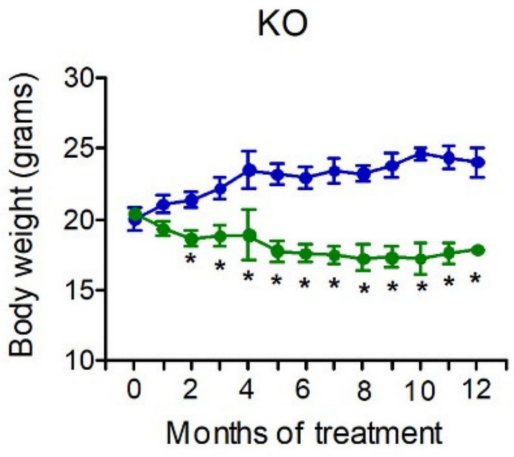

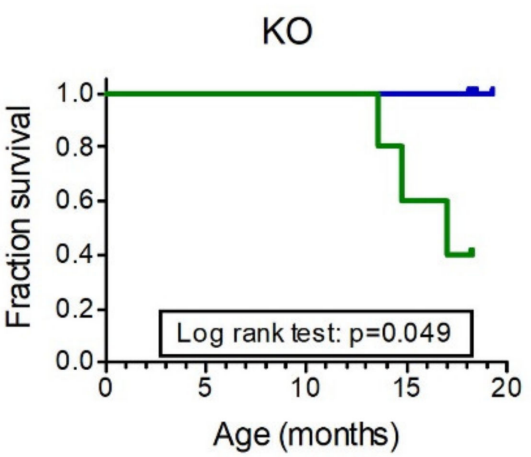

Figure 4. Long-term treatment with low DSF dose. Two-month-old mice were fed on standard or DSF-supplemented diets at an estimated dose of $100 \mathrm{mg} / \mathrm{kg} /$ day for 16 months. (A) Body weight; data are shown as mean $\pm \mathrm{SEM} ; n=5$ mice per group; ${ }^{*} p<0.05$ compared to untreated animals. (B) Kaplan-Meier survival curves in the same animals.

Evaluation of liver function tests revealed increased plasma alkaline phosphatase levels in DSF-treated animals compared to untreated animals, which did not exceed the normal range (Table S1). All other studied markers were unaltered (Table S1). By standard liver histology techniques, we did not observe abnormal changes, including fibrosis, steatosis, inflammation, or signs of hepatocellular damage (data not shown).

After sacrifice, we measured the impact of DSF on cystine accumulation and apoptosis. As shown in Figure ??B, cystine content was decreased in the kidneys, liver, and heart of DSF-treated KO mice. Kidney histology did not show pathological changes, including tubular atrophy, interstitial fibrosis, mesangial expansion, or glomerular damage in both DSF-treated and untreated $\mathrm{KO}$ animals (data not shown). However, an increased number of apoptotic cells was observed in untreated cystinotic kidneys (Figure ??C), but not in kidneys from $\mathrm{KO}$ animals treated with high-dose DSF (Figure ??C), confirming the in vitro observations (Figure 2B).

\subsection{In Vivo Studies: Murine Treatment with Low DSF Dose}

Animals receiving $100 \mathrm{mg} / \mathrm{kg} /$ day DSF dose were monitored for 18 months. Urine parameters were available every 2 months, until the age of 1 year. Intermediate results are illustrated in Figure S1; results at 12 months are detailed in Table ??. At 1 year of age, KO mice had markedly more albuminuria, low-molecular weight proteinuria, and diuresis compared to WT mice. DSF treatment failed to improve urinary parameters. 
Table 2. Urinary parameters in WT and KO mice at 12 months of age, after 10 months of treatment with DSF.

\begin{tabular}{|c|c|c|c|c|c|}
\hline \multirow[b]{2}{*}{ Urine Tests } & \multirow[b]{2}{*}{ Measure Unit } & \multicolumn{2}{|c|}{ WT } & \multicolumn{2}{|c|}{$\mathrm{KO}$} \\
\hline & & Untreated & $\begin{array}{l}\text { DSF } \\
100\end{array}$ & Untreated & $\begin{array}{c}\text { DSF } \\
100\end{array}$ \\
\hline Albumin & $\mu \mathrm{g} / \mathrm{mg}$ Creatinine & $\begin{array}{c}5.05 \\
{[4.26-6.40]}\end{array}$ & $\begin{array}{c}11.5 \\
{[5.68-13.8]}\end{array}$ & $\begin{array}{c}15.1 \\
{[14.4-36.2]^{\S}}\end{array}$ & $\begin{array}{c}19.0 \\
{[17.9-36.8]}\end{array}$ \\
\hline Glucose & $\mathrm{mg} / \mathrm{mg}$ Creatinine & $\begin{array}{c}0.18 \\
{[0.08-0.84]}\end{array}$ & $\begin{array}{c}0.42 \\
{[0.19-1.12]}\end{array}$ & $\begin{array}{c}2.71 \\
{[1.34-3.85]^{\S}}\end{array}$ & $\begin{array}{c}9.00 \\
{[4.21-29.4]}\end{array}$ \\
\hline LMWP & $\mu \mathrm{g} / \mathrm{mg}$ Creatinine & $\begin{array}{c}16.4 \\
{[5.30-26.6]}\end{array}$ & $\begin{array}{c}35.4 \\
{[26.8-63.2]}\end{array}$ & $\begin{array}{c}1939 \\
{[985-4353] \S}\end{array}$ & $\begin{array}{c}5758 \\
{[1434-13972]}\end{array}$ \\
\hline Calcium & $\mathrm{mg} / \mathrm{mg}$ Creatinine & $\begin{array}{c}0.30 \\
{[0.25-0.35]}\end{array}$ & $\begin{array}{c}0.26 \\
{[0.22-0.35]}\end{array}$ & $\begin{array}{c}0.32 \\
{[0.30-0.57]}\end{array}$ & $\begin{array}{c}0.42 \\
{[0.21-0.54]}\end{array}$ \\
\hline Phosphate & $\mathrm{mg} / \mathrm{mg}$ Creatinine & $\begin{array}{c}2.08 \\
{[0.70-2.77]}\end{array}$ & $\begin{array}{c}1.74 \\
{[0.17-2.50]}\end{array}$ & $\begin{array}{c}2.93 \\
{[1.47-3.56]}\end{array}$ & $\begin{array}{c}2.62 \\
{[1.03-3.53]}\end{array}$ \\
\hline Diuresis & $\mathrm{ml}$ & $\begin{array}{c}1.20 \\
{[0.75-2.10]}\end{array}$ & $\begin{array}{c}1.75 \\
{[1.62-2.00]}\end{array}$ & $\begin{array}{c}3.05 \\
{[2.32-3.25]^{\S}}\end{array}$ & $\begin{array}{c}3.00 \\
{[1.60-3.25]}\end{array}$ \\
\hline
\end{tabular}

Data are represented as median [interquartile range]; $n=5$ mice per group. Low molecular weight proteins (LMWP), $100 \mathrm{mg} / \mathrm{kg} / \mathrm{day}$ DSF dose (DSF 100). ${ }^{\S} p<0.05$ untreated WT mice vs. untreated KO mice; ${ }^{*} p<0.05$ untreated WT mice vs. treated KO mice.

On average, body weight of mice treated with DSF was lower compared to untreated animals (Figure ??A). After the age of 12 months, mice were followed until death or sacrificed at 18 months. As shown in Figure ??B, treatment with DSF decreased survival only in $\mathrm{KO}$ animals $(p=0.049)$.

During the initial dose-testing assays, we also tested a pilot cohort of five $\mathrm{KO}$ mice treated with a DSF dose of $\sim 50 \mathrm{mg} / \mathrm{kg} /$ day. Of these, three animals died between 16 and 18 months. Since most animals treated with the $100 \mathrm{mg} / \mathrm{kg} /$ day dose had died before the age of 18 months, we pooled together the data of four surviving $\mathrm{KO}$ animals treated with either 50 or $100 \mathrm{mg} / \mathrm{kg} /$ day of DSF. These results are shown in Table S2 and Supplementary Figure S2. We observed no significant differences between treated and untreated animals. In particular, we failed to observe a decrease in tissue cystine content, unlike what we observed at 5 months in animals treated with the $200 \mathrm{mg} / \mathrm{kg} /$ day dose. This was not related to decreased food intake, which was monitored, and is further substantiated by high DDC levels in tissues obtained from treated animals (Figure S2).

\subsection{In Vivo Studies: Zebrafish Embryos and Larvae}

In parallel to murine studies, we performed assays on cystinotic (KO) zebrafish to assess DSF safety. WT and KO zebrafish embryos were treated within $1 \mathrm{~h}$ after fertilization with different concentrations of DSF. Hatching rates were monitored at 48, 72, and $96 \mathrm{~h}$ post-fertilization (hpf) and dysmorphic features were analyzed at $96 \mathrm{hpf}$. Embryos were monitored for mortality rates at different time points $(6,12,24,48,72$, and $96 \mathrm{hpf})$. As shown in Figure ??A, the mortality rate was higher in untreated KO larvae than in untreated WT larvae $(p<0.007)$. Larvae mortality increased very rapidly with increasing doses of DSF in KO fishes (Figure ??B). The 50\% lethal concentration of DSF (LD50) was $146 \mu \mathrm{M}$ in WT embryos and $2 \mu \mathrm{M}$ in KO embryos (96 hpf). 
A



$\operatorname{DSF}(\mu \mathrm{M})-\longrightarrow 0$
B

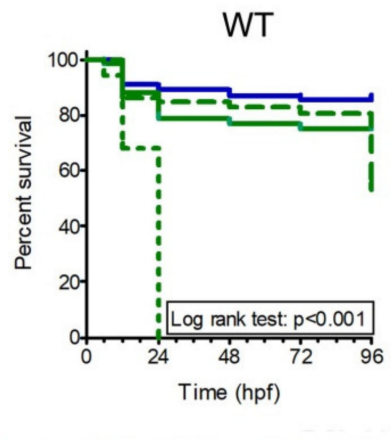

$0 \quad \cdots 1000--100$

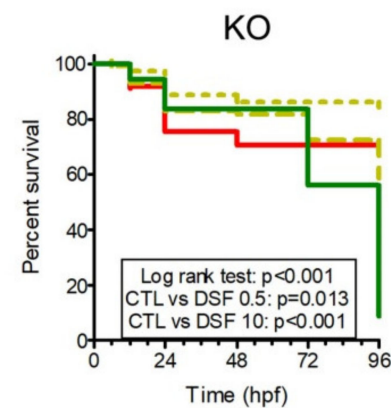

$10--1 \cdots 0.5$

Figure 5. Effect of DSF on survival in wild-type (WT) and cystinotic (KO) zebrafish embryos and larvae. (A) Survival curves of untreated KO $(n=82)$ and WT $(n=126)$ embryos and larvae. (B) Survival curves of WT and KO embryos treated with different DSF concentrations as indicated in the figure legend. All curves are obtained from at least 100 larvae. Survival was monitored for $96 \mathrm{~h}$ post-fertilization (hpf).

Similarly, hatching was delayed and larval malformations were significantly more frequent in zebrafish treated with DSF (Figure ??A-C). These effects were observed at very low DSF concentrations $(0.5 \mu \mathrm{M})$ in $\mathrm{KO}$ larvae, and were remarkably less pronounced in WT larvae, indicating increased sensitivity to DSF in cystinotic larvae. The average cystine levels after exposure of KO larvae to $1 \mu \mathrm{M}$ DSF for $120 \mathrm{~h}$ was $2.4 \pm 0.87$ and $3.7 \pm 0.54 \mathrm{nM}$ cystine/mg protein in untreated $(n=11)$ and treated $(n=3)$ larval homogenates, respectively. At these DSF concentrations, the drug had no apparent cystine lowering effect. At higher concentrations, DSF was too toxic. Taken together, the above results suggest that DSF has a specific toxicity in cystinotic zebrafish.

\subsection{N-Acetyl Cysteine Can Rescue Disulfiram Toxicity in Cystinotic Cells}

Based on our in vivo results, we hypothesized that DSF reacts with free cellular thiols, oxidizing the cells (Figure ??).

We therefore measured in vitro the redox status in cystinotic ciPTEC treated with $10 \mu \mathrm{M}$ DSF for $24 \mathrm{~h}$. This dose was shown to decrease cystine accumulation and apoptosis in vitro (Figure 2). Under these conditions, the levels of reactive oxygen species (ROS) remained stable $(0.99 \pm 0.003$ vs. $0.79 \pm 0.07 ; p=0.09$, in untreated and treated cells, respectively), while the GSH/GSSG ratio decreased by more than 50\% (127 \pm 3 vs. $59 \pm 10$; $p<0.02$ in untreated and treated cells, respectively). In addition, we also confirmed higher cell mortality in cystinotic cells exposed to DSF (LD50: $107 \mu \mathrm{M}$ in cystinotic cells vs. $275 \mu \mathrm{M}$ in wild-type cells) (Figure ??A). Cystinotic-specific DSF toxicity was completely abolished when cells were cultured with L-Cysteine or with $\mathrm{N}$-acetyl cysteine (Figure ??B,C). 
A
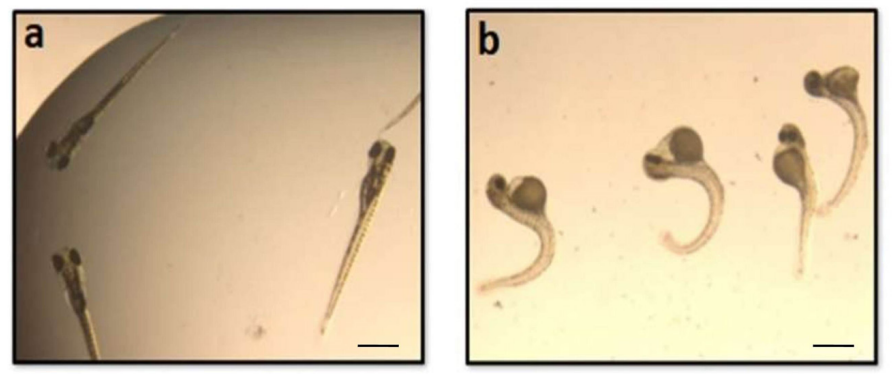

B
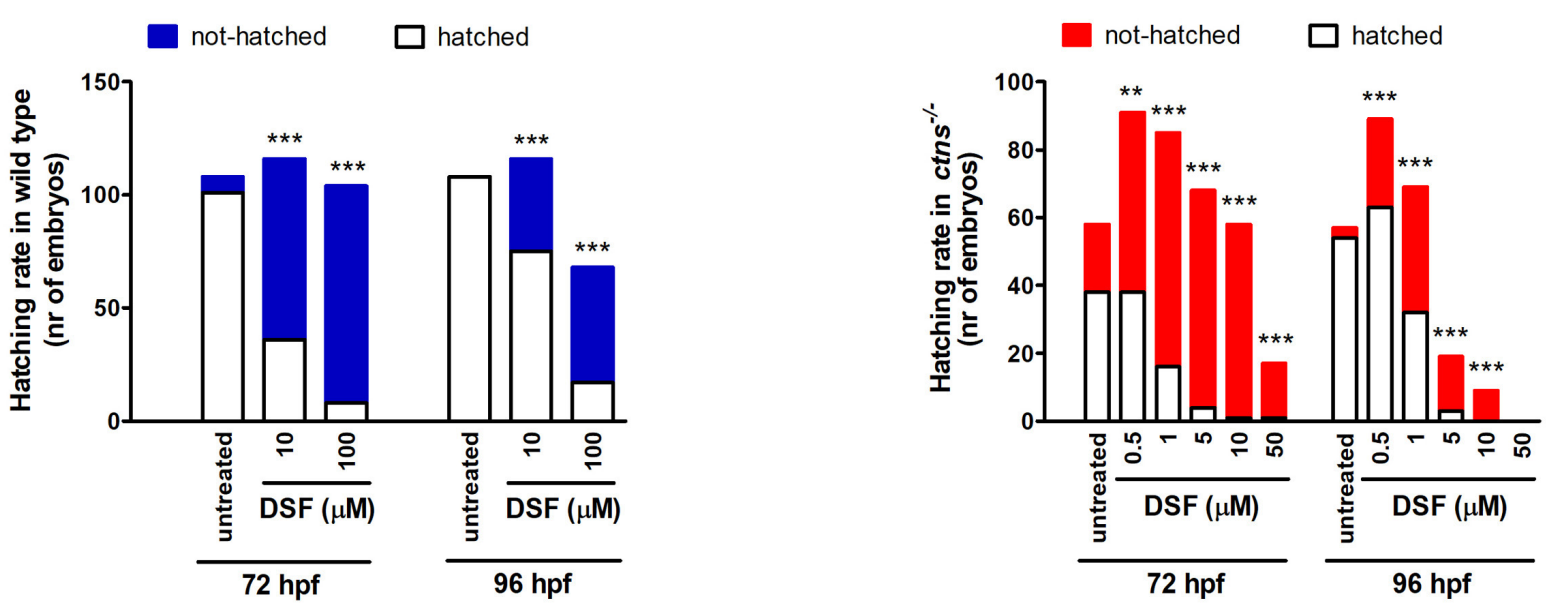

C


Figure 6. Effect of DSF on hatching and deformity rate in wild-type (WT) and cystinotic (KO) zebrafish embryos and larvae. (A) Representative microscopy image of WT (a) and KO (b) zebrafish embryos. Scale bar: $1 \mathrm{~mm}$. (B,C) Hatching and deformity rates in embryos and larvae treated with different doses of DSF (WT: $n=116$ and 104 at 10 and $100 \mu \mathrm{M}$, respectively; KO: $n=91,85,68,58$, and 17 , at $0.5,1,5,10$, and $50 \mu \mathrm{M}$, respectively). Deformity rates were evaluated after 96 hpf. ${ }^{*} p<0.05$, ${ }^{* *} p<0.01,{ }^{* * *} p<0.001$ compared to untreated embryos or larvae. 


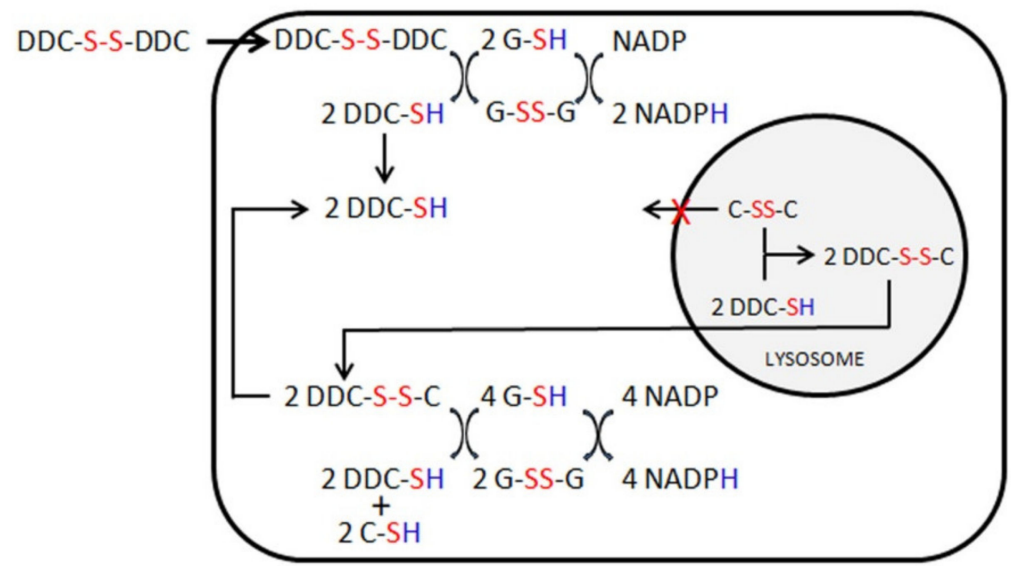

Figure 7. A hypothetical model illustrating the effects of DSF in cystinotic cells. DSF (DDC-S-S-DDC) is a disulfide that is reduced to diethyldithiocarbamate (DDC) in the cytosol, consuming GSH and other free thiols. Consequently, cells are more exposed to free radicals, causing oxidative cell damage and death. Similarly to cysteamine, reduced DDC can react with cystine (C-SS-C) in lysosomes, forming a mixed disulfide (DDC-S-S-C) that allows clearance of cystine.

A

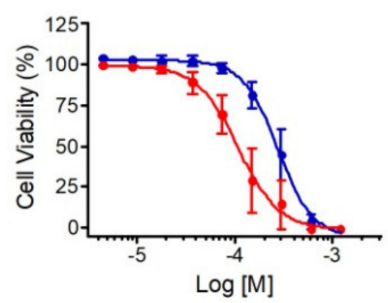

B

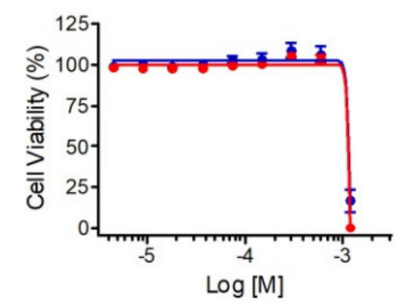

C

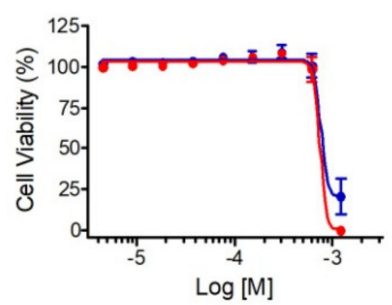

Healthy ciPTEC

Cystinotic ciPTEC

Figure 8. DSF toxicity in cystinotic cells. (A) Cell viability was measured in healthy and cystinotic ciPTEC after incubation with increasing DSF doses (from $4.5 \mu \mathrm{M}$ to $1.2 \mathrm{mM}$ ). (B,C) The same experiment was repeated after incubation with L-cysteine $(1.8 \mathrm{mM})$ or $\mathrm{N}$-acetyl cysteine $(1.8 \mathrm{mM})$ for $24 \mathrm{~h}$.

\section{Discussion}

Cystinosis is a severe metabolic disease causing cystine accumulation in most tissues. Currently, the disease is treated with cysteamine. This treatment improves clinical outcome, but progression of chronic kidney failure cannot be prevented and other long-term complications still develop in many patients. Our study aimed at identifying new treatments for cystinosis. To this end, we screened a compound library using two characteristic phenotypes of cystinotic cells, namely cystine accumulation and high propensity to undergo apoptosis [? ]. Among the compounds that we identified, we selected DSF as a potential molecule for drug repositioning.

DSF is a synthetic molecule that was produced by the German chemist M. Grodzki in 1881 [? ]. It was initially used in the rubber industry and was subsequently investigated for clinical use. In the early 1940s, DSF was proposed for treating scabies and worm infections, based on its copper chelating activity. These clinical assays revealed the potential use of DSF to treat alcohol abuse [? ]. DSF diffuses rapidly in most tissues [? ], where it interacts with sulfhydryl residues of proteins [? ? ]. In particular, DSF inhibits acetaldehyde dehydrogenase in the liver, and renders subjects intolerant to alcohol. Recently, DSF has been reported to have in vitro and in vivo anti-inflammatory properties [? ], which may be relevant in cystinosis, since cystine crystals cause inflammation [? ? ]. 
Our data show that DSF decreases cystine accumulation and increases resistance of cystinotic cells to apoptosis in vitro. Apoptosis of cystinotic cells has been attributed to cysteinylation of protein kinase $\mathrm{C}$ delta [? ] and/or to oxidative damage of mitochondria [? ].

DSF appeared particularly interesting because it has been used for more than 50 years in humans for various clinical purposes. It has a relatively good safety profile in subjects treated for alcohol abuse, and has a very low cost, which would be extremely valuable in low-income countries. To our knowledge, DSF has never been used in cystinosis. Unfortunately, our results show that prolonged exposure to DSF is toxic to mice, and that toxicity is markedly increased in cystinotic animals. Higher toxicity was also confirmed in zebrafish harboring a nonsense mutation in exon 8 of the ctns orthologue gene. In this model, we observed increased lethality and severe developmental abnormalities at early embryonic stages. We did not observe a cystine-depleting effect, unlike what has been reported with cysteamine [? ], probably because larvae died at cystine-lowering concentrations. Although disappointing, these results demonstrate the importance of a thorough drug evaluation, even when using a drug repositioning approach based on molecules where extensive clinical data are available. Of note, we cannot exclude that an intermittent treatment would have produced positive results with fewer side effects.

The murine cystinotic model that was used in these studies reproduces only in part the human disease. Similarly to humans, mice accumulate large amounts of intracellular cystine, but kidney disease develops later, and many long-term complications of cystinosis are not observed. From the renal standpoint, the phenotype is characterized by progressive development of low molecular weight proteinuria from three months of age, followed by albuminuria around 6 months of age, and chronic renal failure around one year of age. Glycosuria has a biphasic evolution. It increases from 3 to 6 months and regress around the age of 10 months. This trend has been observed in different laboratories using the same mouse model and has no clear explanation. It is remarkable that glycosuria regressed faster in animals treated with DSF, which may be related to the hypoglycemic effect of DSF. This has been shown in obese mice treated with similar doses of DSF [? ]. Remarkably, the authors of this latter study observed that DSF increases energy expenditure and causes weight loss [? ], which may explain, at least in part, poor animal growth in our study.

The reasons for the observed increased mortality in DSF-treated $\mathrm{KO}$ mice remains an open question. The zebrafish data point to a specific toxic effect of DSF on cystinotic larvae. In other cell models, oxidative stress has been proposed to be the main mechanism of DSF-mediated cell toxicity [? ? ? ]. Cystinotic cells have relative glutathione deficiency and produce more ROS when exposed to oxidative stress [? ? ? ]. Cell oxidation can also cause apoptosis. The anti-oxidative proprieties of cysteamine may explain the anti-apoptotic effects of this drug [? ? ]. In addition, antioxidant treatment has been shown to protect proximal tubular cells in the same cystinotic mouse model [? ? ]. Further supporting the role of pathogenic oxidation in cystinosis, we observed that N-acetylcysteine and L-cysteine restore cell viability of cystinotic cells treated with DSF.

We also observed the formation of mixed disulfides of DDC with cysteine, similarly to what has been described with cysteamine. This finding supports the cystine-lowering effect of DSF, but also proves that DSF is reduced to DDC in cells, which can severely oxidize cells, as illustrated in Figure ??. Conversely, DSF may have positive effects. In particular, it may prevent apoptosis by forming mixed disulfides with caspase-3, which inhibits the enzymatic activation of the apoptosis cascade [? ? ]. Our results show, however, that the net balance between these opposite effects is unfavorable in cystinotic cells.

Supplementary Materials: The following are available online at https:/ /www.mdpi.com/article/10 .3390/cells10123294/s1, Figure S1: Urine parameters in mice: long-term treatment with low dose DSF. Wild-type (dashed line) and cystinotic (continuous line) mice were fed on standard (blue line) or DSF-supplemented- diet (100 mg/kg/day, green line). Urine was collected every two months. Data are reported as median values; $n=5$ mice per group. Figure S2: Cystine and diethyldithiocarbamate (DDC) in 18-month-old mice treated with low DSF doses. WT and KO mice were fed on standard 
diet or DSF supplemented diets at 50 (square green dots) and 100 (round green dots) $\mathrm{mg} / \mathrm{kg} /$ day. Cystine (A) and DDC (B) content in kidneys, liver and heart. Each dot represents the mean cystine values measured on two aliquots of tissue per animal; $n=4$ or 5 per group. ${ }^{*} p<0.05,{ }^{* *} p<0.01$, *** $p<0.001$. Table S1: Hepatotoxicity parameters measured in plasma of WT and KO mice treated with disulfiram (DSF) for three months. Table S2: Hepatotoxicity and urinary parameters in WT and KO mice at 18 months of age, after 16 months of treatment with disulfiram (DSF).

Author Contributions: Conceptualization, F.E.; methodology, A.T. and M.A.E.; validation, B.M.G.; formal analysis, M.C.; investigation, A.T., M.A.E., F.B., E.D.L., S.B., M.J.J., A.J., S.C., A.P., C.D.S., L.R.R., I.G. and P.F.; resources, L.P.v.d.H., C.D.-V. and B.M.G.; writing-original draft preparation, A.T. and F.E.; project administration, A.T., E.L. and R.M.; funding acquisition, F.E., E.L. and R.M. All authors have read and agreed to the published version of the manuscript.

Funding: This research was funded by the Cystinosis Research Foundation (grant no. CRFS-2014), the Italian Ministry of Health (Ricerca Corrente grant no. RC2015), E-rare European Union (grant no. E-Rare-2 JTC 2014), and the Foundation of Scientific Research Flanders (award 11Y5216N).

Institutional Review Board Statement: The study was conducted in accordance with the European 2010/63/EU directive on the protection of animals used for scientific purposes, and authorized by the Italian Ministry of Health (authorization number 230/2015-PR).

Conflicts of Interest: The authors declare no conflict of interest.

\section{References}

1. Elmonem, M.A.; Veys, K.R.; Soliman, N.A.; van Dyck, M.; van den Heuvel, L.P.; Levtchenko, E. Cystinosis: A review. Orphanet J. Rare Dis. 2016, 11, 47. [CrossRef]

2. Emma, F.; Nesterova, G.; Langman, C.; Labbe, A.; Cherqui, S.; Goodyer, P.; Janssen, M.C.; Greco, M.; Topaloglu, R.; Elenberg, E.; et al. Nephropathic cystinosis: An international consensus document. Nephrol. Dial. Transplant. 2014, 29 (Suppl. 4), iv87-iv94. [CrossRef] [PubMed]

3. Kasimer, R.N.; Langman, C.B. Adult complications of nephropathic cystinosis: A systematic review. Pediatr. Nephrol. 2021, 36, 223-236. [CrossRef]

4. Gaide Chevronnay, H.P.; Janssens, V.; Van Der Smissen, P.; N'Kuli, F.; Nevo, N.; Guiot, Y.; Levtchenko, E.; Marbaix, E.; Pierreux, C.E.; Cherqui, S.; et al. Time course of pathogenic and adaptation mechanisms in cystinotic mouse kidneys. J. Am. Soc. Nephrol. 2014, 25, 1256-1269. [CrossRef]

5. Park, M.; Helip-Wooley, A.; Thoene, J. Lysosomal cystine storage augments apoptosis in cultured human fibroblasts and renal tubular epithelial cells. J. Am. Soc. Nephrol. 2002, 13, 2878-2887. [CrossRef] [PubMed]

6. Taranta, A.; Bellomo, F.; Petrini, S.; Polishchuk, E.; De Leo, E.; Rega, L.R.; Pastore, A.; Polishchuk, R.; De Matteis, M.A.; Emma, F. Cystinosin-LKG rescues cystine accumulation and decreases apoptosis rate in cystinotic proximal tubular epithelial cells. Pediatr. Res. 2017, 81, 113-119. [CrossRef]

7. Jezegou, A.; Llinares, E.; Anne, C.; Kieffer-Jaquinod, S.; O’Regan, S.; Aupetit, J.; Chabli, A.; Sagne, C.; Debacker, C.; ChadefauxVekemans, B.; et al. Heptahelical protein PQLC2 is a lysosomal cationic amino acid exporter underlying the action of cysteamine in cystinosis therapy. Proc. Natl. Acad. Sci. USA 2012, 109, E3434-E3443. [CrossRef]

8. Emma, F.; Hoff, W.V.; Hohenfellner, K.; Topaloglu, R.; Greco, M.; Ariceta, G.; Bettini, C.; Bockenhauer, D.; Veys, K.; Pape, L.; et al. An international cohort study spanning five decades assessed outcomes of nephropathic cystinosis. Kidney Int. 2021, 100, 1112-1123. [CrossRef] [PubMed]

9. Bellomo, F.; De Leo, E.; Taranta, A.; Giaquinto, L.; Di Giovamberardino, G.; Montefusco, S.; Rega, L.R.; Pastore, A.; Medina, D.L.; Di Bernardo, D.; et al. Drug repurposing in rare diseases: An integrative study of drug screening and transcriptomic analysis in nephropathic cystinosis. Int. J. Mol. Sci. 2021. Submitted.

10. Wilmer, M.J.; Saleem, M.A.; Masereeuw, R.; Ni, L.; van der Velden, T.J.; Russel, F.G.; Mathieson, P.W.; Monnens, L.A.; van den Heuvel, L.P.; Levtchenko, E.N. Novel conditionally immortalized human proximal tubule cell line expressing functional influx and efflux transporters. Cell Tissue Res. 2010, 339, 449-457. [CrossRef] [PubMed]

11. Pastore, A.; Lo Russo, A.; Greco, M.; Rizzoni, G.; Federici, G. Semiautomated method for determination of cystine concentration in polymorphonuclear leukocytes. Clin. Chem. 2000, 46, 574-576. [CrossRef] [PubMed]

12. Jamalpoor, A.; van Gelder, C.A.; Yousef Yengej, F.A.; Zaal, E.A.; Berlingerio, S.P.; Veys, K.R.; Pou Casellas, C.; Voskuil, K.; Essa, K.; Ammerlaan, C.M.; et al. Cysteamine-bicalutamide combination therapy corrects proximal tubule phenotype in cystinosis. $E M B O$ Mol. Med. 2021, 13, e13067. [CrossRef] [PubMed]

13. Nevo, N.; Chol, M.; Bailleux, A.; Kalatzis, V.; Morisset, L.; Devuyst, O.; Gubler, M.C.; Antignac, C. Renal phenotype of the cystinosis mouse model is dependent upon genetic background. Nephrol. Dial. Transplant. 2010, 25, 1059-1066. [CrossRef]

14. Elmonem, M.A.; Khalil, R.; Khodaparast, L.; Khodaparast, L.; Arcolino, F.O.; Morgan, J.; Pastore, A.; Tylzanowski, P.; Ny, A.; Lowe, M.; et al. Cystinosis (ctns) zebrafish mutant shows pronephric glomerular and tubular dysfunction. Sci. Rep. 2017, 7, 42583. [CrossRef] 
15. Harper, C.; Lawrence, C. The Laboratory Zebrafish, 1st ed.; CRC Press: Boca Raton, FL, USA, 2011; pp. 1-274.

16. Kragh, H. From disulfiram to antabuse: The invention of a drug. Bull. Hist. Chem. 2008, 33, 82-88.

17. Johansson, B. A review of the pharmacokinetics and pharmacodynamics of disulfiram and its metabolites. Acta Psychiatr. Scand. 1992, 369, 15-26. [CrossRef]

18. Lipsky, J.J.; Shen, M.L.; Naylor, S. In vivo inhibition of aldehyde dehydrogenase by disulfiram. Chem. Biol. Interact. 2001, 130-132, 93-102. [CrossRef]

19. Vallari, R.C.; Pietruszko, R. Human aldehyde dehydrogenase: Mechanism of inhibition of disulfiram. Science 1982, 216, 637-639. [CrossRef]

20. Deng, W.; Yang, Z.; Yue, H.; Ou, Y.; Hu, W.; Sun, P. Disulfiram suppresses NLRP3 inflammasome activation to treat peritoneal and gouty inflammation. Free Radic. Biol. Med. 2020, 152, 8-17. [CrossRef] [PubMed]

21. Prencipe, G.; Caiello, I.; Cherqui, S.; Whisenant, T.; Petrini, S.; Emma, F.; De Benedetti, F. Inflammasome activation by cystine crystals: Implications for the pathogenesis of cystinosis. J. Am. Soc. Nephrol. 2014, 25, 1163-1169. [CrossRef] [PubMed]

22. Elmonem, M.A.; Makar, S.H.; van den Heuvel, L.; Abdelaziz, H.; Abdelrahman, S.M.; Bossuyt, X.; Janssen, M.C.; Cornelissen, E.A.; Lefeber, D.J.; Joosten, L.A.; et al. Clinical utility of chitotriosidase enzyme activity in nephropathic cystinosis. Orphanet J. Rare Dis. 2014, 9, 155. [CrossRef]

23. Park, M.A.; Pejovic, V.; Kerisit, K.G.; Junius, S.; Thoene, J.G. Increased apoptosis in cystinotic fibroblasts and renal proximal tubule epithelial cells results from cysteinylation of protein kinase Cdelta. J. Am. Soc. Nephrol. 2006, 17, 3167-3175. [CrossRef]

24. De Rasmo, D.; Signorile, A.; De Leo, E.; Polishchuk, E.V.; Ferretta, A.; Raso, R.; Russo, S.; Polishchuk, R.; Emma, F.; Bellomo, F. Mitochondrial Dynamics of Proximal Tubular Epithelial Cells in Nephropathic Cystinosis. Int. J. Mol. Sci. 2019, 21, 192. [CrossRef] [PubMed]

25. Bernier, M.; Mitchell, S.J.; Wahl, D.; Diaz, A.; Singh, A.; Seo, W.; Wang, M.; Ali, A.; Kaiser, T.; Price, N.L.; et al. Disulfiram Treatment Normalizes Body Weight in Obese Mice. Cell Metab. 2020, 32, 203-214.e4. [CrossRef] [PubMed]

26. Bernier, M.; Harney, D.; Koay, Y.C.; Diaz, A.; Singh, A.; Wahl, D.; Pulpitel, T.; Ali, A.; Guiterrez, V.; Mitchell, S.J.; et al. Elucidating the mechanisms by which disulfiram protects against obesity and metabolic syndrome. NPJ Aging Mech. Dis. 2020, 6, 8. [CrossRef] [PubMed]

27. Hothi, P.; Martins, T.J.; Chen, L.; Deleyrolle, L.; Yoon, J.G.; Reynolds, B.; Foltz, G. High-throughput chemical screens identify disulfiram as an inhibitor of human glioblastoma stem cells. Oncotarget 2012, 3, 1124-1136. [CrossRef] [PubMed]

28. Allensworth, J.L.; Evans, M.K.; Bertucci, F.; Aldrich, A.J.; Festa, R.A.; Finetti, P.; Ueno, N.T.; Safi, R.; McDonnell, D.P.; Thiele, D.J.; et al. Disulfiram (DSF) acts as a copper ionophore to induce copper-dependent oxidative stress and mediate anti-tumor efficacy in inflammatory breast cancer. Mol. Oncol. 2015, 9, 1155-1168. [CrossRef]

29. Falls-Hubert, K.C.; Butler, A.L.; Gui, K.; Anderson, M.; Li, M.; Stolwijk, J.M.; Rodman, S.N., III; Solst, S.R.; Tomanek-Chalkley, A.; Searby, C.C.; et al. Disulfiram causes selective hypoxic cancer cell toxicity and radio-chemo-sensitization via redox cycling of copper. Free Radic. Biol. Med. 2020, 150, 1-11. [CrossRef] [PubMed]

30. Mannucci, L.; Pastore, A.; Rizzo, C.; Piemonte, F.; Rizzoni, G.; Emma, F. Impaired activity of the gamma-glutamyl cycle in nephropathic cystinosis fibroblasts. Pediatr. Res. 2006, 59, 332-335. [CrossRef] [PubMed]

31. Levtchenko, E.; de Graaf-Hess, A.; Wilmer, M.; van den Heuvel, L.; Monnens, L.; Blom, H. Altered status of glutathione and its metabolites in cystinotic cells. Nephrol. Dial. Transplant. 2005, 20, 1828-1832. [CrossRef]

32. Cherqui, S.; Courtoy, P.J. The renal Fanconi syndrome in cystinosis: Pathogenic insights and therapeutic perspectives. Nat. Rev. Nephrol. 2017, 13, 115-131. [CrossRef] [PubMed]

33. Bellomo, F.; Signorile, A.; Tamma, G.; Ranieri, M.; Emma, F.; De Rasmo, D. Impact of atypical mitochondrial cyclic-AMP level in nephropathic cystinosis. Cell Mol. Life Sci. 2018, 75, 3411-3422. [CrossRef]

34. Galarreta, C.I.; Forbes, M.S.; Thornhill, B.A.; Antignac, C.; Gubler, M.C.; Nevo, N.; Murphy, M.P.; Chevalier, R.L. The swan-neck lesion: Proximal tubular adaptation to oxidative stress in nephropathic cystinosis. Am. J. Physiol. Renal. Physiol. 2015, 308, F1155-F1166. [CrossRef] [PubMed]

35. Festa, B.P.; Chen, Z.; Berquez, M.; Debaix, H.; Tokonami, N.; Prange, J.A.; Hoek, G.V.; Alessio, C.; Raimondi, A.; Nevo, N.; et al. Impaired autophagy bridges lysosomal storage disease and epithelial dysfunction in the kidney. Nat. Commun. 2018, 9, 161. [CrossRef]

36. Nobel, C.S.; Kimland, M.; Nicholson, D.W.; Orrenius, S.; Slater, A.F. Disulfiram is a potent inhibitor of proteases of the caspase family. Chem. Res. Toxicol. 1997, 10, 1319-1324. [CrossRef] [PubMed]

37. Nobel, C.S.; Burgess, D.H.; Zhivotovsky, B.; Burkitt, M.J.; Orrenius, S.; Slater, A.F. Mechanism of dithiocarbamate inhibition of apoptosis: Thiol oxidation by dithiocarbamate disulfides directly inhibits processing of the caspase-3 proenzyme. Chem. Res. Toxicol. 1997, 10, 636-643. [CrossRef] [PubMed] 